\title{
An optimized recipe for cloning of the polymerase chain reaction-amplified DNA inserts into plasmid vectors ${ }^{*}$
}

\author{
Zeki Topcu ${ }^{凶}$ \\ Department of Pharmaceutical Biotechnology, School of Pharmacy, Ege University, Izmir, Turkey
}

Received: 29 May, 2000; accepted: 12 June, 2000

Key words: cloning, PCR, bacterial transformation

\begin{abstract}
This study compares a number of parameters that are important in the ligation of the polymerase chain reaction-amplified DNA inserts into plasmid vectors and their efficient transformation to bacterial cells. The parameters covered were: T4 polynucleotide kinase treatment followed by either the large fragment of $E$. coli DNA polymerase or T4 DNA polymerase reactions, the amount of T4 DNA ligase, temperature and duration of ligation, molar ratio of insert to vector as well as the total DNA concentration. The results show that the T4 polynucleotide kinase-treated group without further enzymatic manipulation, at an insert to vector ratio of 3:1 gave the highest recombination efficiency when $10 \mu \mathrm{g} / \mathrm{ml}$ DNA and 20 units T4 DNA ligase were applied for ligation for $12 \mathrm{~h}$ at $4^{\circ} \mathrm{C}$.
\end{abstract}

The requirement for template instruction in adding deoxyribonucleotide on DNA primers is a characteristic feature of DNA polymerases, a property not observed in other nucleotidyl transferases, such as terminal deoxynucleotidyl transferases (TdT) [1]. However, a number of DNA polymerases, including that from Thermus aquaticus, add nucleotides to the $3^{\prime}$ ends of double-stranded DNA with a bias for dAMP in a template-independent way [2]. Unless linked to adaptors with re- striction enzyme sites engineered to produce cohesive termini, PCR products are known to be relatively inefficient in constructing recombinant DNA molecules and a variety of tips to overcome this difficulty are available in commonly used experimental protocols [3].

As a part of biochemical characterization of the mitochondrial type I DNA topoisomerases ( $m$ t topoI), studies on the effects of certain mitochondrial DNA (mtDNA) sequences on the enzyme's affinity required construction of a

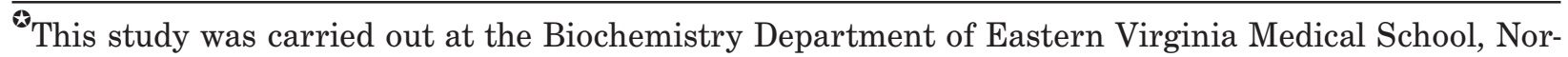
folk, VA, U.S.A.

${ }^{凶}$ Department of Pharmaceutical Biotechnology, School of Pharmacy, Ege University, 35100, Izmir, Turkey; Phone: (90 232) 388 0110; Fax: (90 232) 388 5258; e-mail: ztopcu@bornova.ege.edu.tr

Abbreviations: TdT, terminal deoxynucleotidyl transferase; mtDNA, mitochondrial DNA; mt topoI, mitochondrial type I topoisomerases; T4 PNK, polynucleotide kinase.
} 
number of recombinant plasmids bearing selected regions of bovine mtDNA (approximately $16500 \mathrm{bp)} \mathrm{[4].} \mathrm{The} \mathrm{selected} \mathrm{regions}$ were the heavy strand origin fragment (H-ori, 15691-149; $797 \mathrm{bp}$ ), light strand origin fragment (L-ori, 5147-5936; 790 bp), transcription termination sequence (Term, 2774-3160; 387 bp) and cytochrome $b$-encoding region (Cyt $b$, 14579-14943; 365 bp). These regions were PCR-amplified and cloned into plasmid vectors. Because of the well-known inefficiency of standard PCR cloning, the study was extended to optimize the parameters that are important in the ligation of PCR products and their transformation to bacterial cells. The parameters covered were: (i) $\mathrm{T} 4$ polynucleotide kinase (T4 PNK) treatment of the PCR products with either large fragment of $E$. coli DNA polymerase I (Klenow enzyme) or T4 DNA polymerase prior to ligation, (ii) the amount of T4 DNA ligase, temperature and duration of ligation, and (iii) molar ratio of insert to vector and total DNA concentration during ligation. Unless stated otherwise, the effect of each parameter was monitored as the number of recombinant clones obtained per $1 \mu \mathrm{g}$ of DNA in the transformed bacterial cells.

\section{MATERIALS AND METHODS}

Chemicals. Klenow enzyme, T4 DNA polymerase, T4 DNA ligase, T4 DNA polynucleotide kinase, pGEM-T vector and JM109 E. coli cells were from Promega (Madison, WI, U.S.A.). Taq DNA polymerase was from Perkin Elmer (Foster, CA, U.S.A.). Ampicillin, isopropyl-1-thio- $\beta$-D-galactoside (IPTG), 5-bromo-4-chloro-3-indolyl- $\beta$-D-galactopyranoside (X-Gal) were from Sigma Chemical Co. (St Louis, MO, U.S.A.).

Preparation of DNA inserts. Using the known bovine mtDNA sequence [5] and a computer-aided program "PRIMER DESIGN", the regions of interest were amplified using a multiplex PCR protocol [25 cycles; $1 \mathrm{~min}$ at $94^{\circ} \mathrm{C}$, $2 \mathrm{~min}$ at $65^{\circ} \mathrm{C}$ and $3 \mathrm{~min}$ at $72^{\circ} \mathrm{C}$ with a final extension of $7 \mathrm{~min}$ at $72^{\circ} \mathrm{C}$ using $100 \mathrm{ng}$ of template DNA, 20 pmole appropriate primers, $1.5 \mathrm{mM}$ dNTP mixture and one unit (u) of Taq DNA polymerase in the buffer containing 83 $\mathrm{mM}\left(\mathrm{NH}_{4}\right)_{2} \mathrm{SO}_{4}, 335 \mathrm{mM}$ Tris/ $\mathrm{HCl}(\mathrm{pH} 8.0)$, $34 \mathrm{mM} \mathrm{MgCl}_{2}, 50 \mathrm{mM} \beta$-mercaptoethanol ( $\beta$-ME), $34 \mathrm{mM}$ EDTA and $850 \mu \mathrm{g} / \mathrm{ml}$ bovine serum albumin (BSA) in $50 \mu \mathrm{l}$ reaction volume] [6]. Sequences of the primers were as follows:

H-ori: Left: 5'ACCAGAGAAGGAGAACAACTAACCTC-3';

Right: 5'-GCTCAAGATGCAGTTAAGTCCAGCTA-3' .

L-ori: Left: 5'-ACGACTCACGTATTCTACCACACTA-3';

Right: 5'-GAACAAGTCAGTTACCGAATCCTCC-3' .

Term: Left: 5'-TACGACCTCGATGTTGGATCAGGAC-3';

Right: 5'-AAGGAATGCTACGGCCAATAGGATG-3' .

Cytb: Left: 5'-AGCCCCATCAAACATTTCATCATGA-3';

Right: 5'-TGCTCCTCAGAATGATATTTGTCCT-3'.

Enzymatic manipulations of insert and vector DNAs. Phosphorylation of $5^{\prime}$ ends with T4 PNK, filling the DNA inserts with dNTPs using Klenow enzyme and converting DNA inserts into blunt ends using T4 DNA polymerase were carried out using standard protocols of molecular biology [3].

Plasmid construction. Amplified DNA inserts were purified using Wizard ${ }^{\circledR}$ columns (Promega, Madison, WI, U.S.A.). Products were phosphorylated at their $5^{\prime}$ termini using T4 PNK and ligated with $3^{\prime}-\mathrm{T}$ overhanging vector, $p G E M^{\circledR}-\mathrm{T}(3.0 \mathrm{~kb})$. The appropriate amount of insert to be used in ligations has been calculated using the following equation; [(amount of vector, ng) $\times$ (size of insert, $\mathrm{kb}) /($ size of vector, $\mathrm{kb}) \times($ molar ratio of insert/vector)] = ng of insert DNA, and the reactions were carried out in $10 \mu \mathrm{l}$ volume according to the manufacturer's instructions [7]. Four transformation sets were prepared for each of the recombinant plasmid using competent JM109 cells. Control recombinant plasmids to match the size of mtDNA-bearing 
recombinant plasmids were also constructed using non-mitochondrial DNA. The cells were grown overnight at $37^{\circ} \mathrm{C}$ on Lauria-Benani (LB) plates containing $50 \mu \mathrm{g} / \mathrm{ml}$ ampicillin, $0.5 \mathrm{mM}$ IPTG and $40 \mu \mathrm{g} / \mathrm{ml}$ X-Gal. A pilot transformation using completely supercoiled pUC 19 plasmid gave a transformation efficiency of $1.2 \times 10^{6}$ recombinant clones per $1 \mu \mathrm{g}$ DNA. Transformants were selected and recombinant plasmids were recovered for gel electrophoresis analyses by alkaline lysis mini-prep [3]. The average number of recombinant clones for each set of experiments were taken into consideration during calculations. The differences between individual plasmid sets were analysed using Student's $t$-test (two-tailed) and the null hypothesis was rejected when $P<0.05$.

\section{RESULTS AND DISCUSSION}

pGEM $^{\circledR}$-T vectors were chosen as a convenient system for cloning because single-T overhangs on the vector have advantage of the 3 ' protruding -A nucleotides on PCR products.

The conditions of the ligation reactions were first subjected to a number of optimizations for three parameters; $4^{\circ} \mathrm{C}$ and $15^{\circ} \mathrm{C}$ as the temperature of the reaction; 10,20 and 50 units of T4 ligase as the amount of enzyme; $4 \mathrm{~h}$ and 12 $\mathrm{h}$ as the duration of ligation. Two of these three parameters were constant in the individual ligation sets and the reactions were carried out according to [6]; 20 units of ligase for $4 \mathrm{~h}$ ligation when the temperature was variable; $4 \mathrm{~h}$ ligation at $4^{\circ} \mathrm{C}$ when the amount of ligase was variable; 20 units of ligase at $4^{\circ} \mathrm{C}$ when the time was variable. The results are summarized in Table 1. The temperature of $4^{\circ} \mathrm{C}$ resulted in a significantly higher overall efficiency of transformation $(P=0.03)$. In the experimental sets focusing on the amount of T4 DNA ligase, both 20 and 50 units of enzyme gave higher efficiency compared to the set with 10 units of enzyme. However, the difference between the groups with 20 and 50 units of enzyme was not significant $(P=0.26)$. The time of the ligase reaction was also influential as $12 \mathrm{~h}$ ligation gave a significantly higher number of transformants than the 4 h-ligation $(P<<0.01)$.

The effects of enzymatic manipulations on the ligation efficiency were investigated under the ligation conditions resulting in its high efficiency i.e. $4^{\circ} \mathrm{C}, 20 \mathrm{u}$ ligase and $12 \mathrm{~h}$ (Table 1). PCR products phosphorylated at their $5^{\prime}$-termini were either filled with dNTPs

Table 1. Effect of temperature versus the amount of ligase and time of ligation on the transformation efficiency of JM109 cells

\begin{tabular}{ll}
\hline $\begin{array}{l}\text { Parameter } \\
\text { investigated }\end{array}$ & $\begin{array}{l}\text { Transformation efficiency } \\
\text { (transformants per } 1 \mu \mathrm{g} \text { of } \\
\text { DNA) }\end{array}$ \\
\hline $\begin{array}{l}\text { Temperature } \\
4^{\circ} \mathrm{C}\end{array}$ & $1.3 \times 10^{4}$ \\
$15^{\circ} \mathrm{C}$ & $2.1 \times 10^{3}$ \\
Amount of ligase & $1.3 \times 10^{3}$ \\
$10 \mathrm{u}$ & $2.4 \times 10^{4}$ \\
$20 \mathrm{u}$ & $1.6 \times 10^{4}$ \\
$50 \mathrm{u}$ & \\
Time of ligation & $1.4 \times 10^{2}$ \\
$4 \mathrm{~h}$ & $3.5 \times 10^{4}$ \\
$12 \mathrm{~h}$ & \\
\hline
\end{tabular}

*See Results and Discussion for statistical evaluation.

using Klenow enzyme or transformed into blunt ends using T4 DNA polymerase. The results are shown in Table 2 in terms of percentage efficiency. Neither Klenow (Table 2, group 2) nor T4 DNA polymerase treatments (Table 2, group 3) made the PCR products compatible for ligation as the efficiency in these two groups was below the detection limit $(<1)$. Both enzymes possess $5^{\prime} \rightarrow 3^{\prime}$ polymerase and $3^{\prime} \rightarrow 5^{\prime}$ exonuclease activities [1]. Although the exonuclease activity of T4 DNA polymerase is more than 200 times as effective as that of Klenow enzyme, this enzyme acts non-processively and indiscriminately on all 3 '-OH termini whether the ends are blunt or have either $3^{\prime}$ - or 5 '-overhangs. The failure to obtain successful ligation could be attributed to the insufficient saturation of 3 ' ends of 
DNA which was due to low affinity of T4 DNA polymerase for $3^{\prime}$ ends. The T4 PNK treatment without further treatment with either polymerase (Table 2, group 4) shows that phosphorylation of PCR-amplified DNA, per

Table 2. Compatibility of PCR products for ligation following the reactions with Klenow enzyme, T4 DNA polymerase or T4 polynucleotide kinase.

Efficiency for individual reaction sets are given in terms of percentage of recombinant colonies after transformation of JM109 cells.

\begin{tabular}{lcccc}
\hline Group & $\begin{array}{c}\text { Klenow } \\
( \pm)\end{array}$ & $\begin{array}{c}\text { T4 pol } \\
( \pm)\end{array}$ & $\begin{array}{c}\text { T4 PNK } \\
( \pm)\end{array}$ & $\begin{array}{c}\text { Efficiency } \\
(\%)\end{array}$ \\
\hline 1 & - & - & - & 16 \\
2 & + & - & + & $<1$ \\
3 & - & + & + & $<1$ \\
4 & - & - & + & 83 \\
\hline
\end{tabular}

$s e$, is sufficient for its processing. However, some recombinant colonies were also detected in the T4 PNK-untreated group (Table 2, group 1).

One of the strategies for high-efficiency cloning of blunt-end DNA molecules involves dephosphorylation of vectors with calf intestinal alkaline phosphatase (CIAP), which catalyses the hydrolysis of $5^{\prime}$-phosphate groups from DNA [8]. Treatment with CIAP has also been found to increase the ligation efficiency of the PCR-amplified inserts, although vector DNAs are not expected to undergo self-ligation due to the presence of 3 '-T overhang (not shown) that could be attributed due to possible removal of overhanging dNTPs by contaminating exonucleases and/or the presence of vectors without $3^{\prime}-\mathrm{T}$ overhangs.

Using the strategy of group 4 of Table 2 as well as the optimized ligation conditions (cf. Table 1) three different molar ratios of insert to vector DNAs were tested (Table 3). The ratios of both 1:3 (group 1) and 1:1 (group 2) gave significantly low transformation efficiencies while the insert to vector ratio of $3: 1$ (group 3) resulted in the highest number of transformants. Statistical analyses of the indi- vidual groups showed a marginal significance for the difference between the first two groups $(P=0.06)$, while the differences between group 3 and either group 1 or 2 were very significant $(P<0.01$, in both cases). A further increase in the relative insert concentration did not improve the ligation efficiency (not shown).

Table 3. Effect of the insert to vector molar ratio in the ligase reaction on the transformation efficiency of JM109 cells

\begin{tabular}{lc}
\hline $\begin{array}{l}\text { Molar ratio of } \\
\text { insert:vector }\end{array}$ & $\begin{array}{l}\text { Transformation efficiency } \\
\text { (transformants per } 1 \mu \mathrm{g} \text { of } \\
\text { DNA) }\end{array}$ \\
\hline $1: 3$ & $1.2 \times 10^{3}$ \\
$1: 1$ & $1.0 \times 10^{3}$ \\
$3: 1$ & $3.5 \times 10^{4}$ \\
\hline
\end{tabular}

${ }^{*}$ See Results and Discussion for statistical evaluation.

DNA concentrations as low as $2 \mu \mathrm{g} / \mathrm{ml}$ and 5 $\mu \mathrm{g} / \mathrm{ml}$ and as high as $50 \mu \mathrm{g} / \mathrm{ml}$ (Table 4 , groups 1, 2 and 4, respectively) gave low transformation efficiency under the experimental conditions derived from the previous steps.

Table 4. Effect of DNA concentration on the transformation efficiency of JM109 cells

\begin{tabular}{ll}
\hline $\begin{array}{l}\text { DNA concentration } \\
(\mu \mathrm{g} / \mathrm{ml})\end{array}$ & $\begin{array}{l}\text { Transformation efficiency } \\
\text { (transformants per } 1 \mu \mathrm{g} \text { of } \\
\text { DNA) }\end{array}$ \\
\hline 2 & $1.4 \times 10^{3}$ \\
5 & $1.6 \times 10^{3}$ \\
10 & $3.5 \times 10^{4}$ \\
50 & $1.8 \times 10^{3}$ \\
\hline
\end{tabular}

${ }^{*}$ See Results and Discussion for statistical evaluation.

The differenceses among those three groups were not significant $(P=1.26)$. Group 3 (Table 4) in which $10 \mu \mathrm{g} / \mathrm{ml}$ DNA was used resulted in an efficiency of $3.5 \times 10^{4}$ transformants $/ \mu$ g DNA which was significantly higher $(P$ $=0.01$ ) than average obtained for groups 1,2 and $4\left(1.6 \times 10^{3}\right.$ transformants $\left./ \mu \mathrm{g}\right)$. 


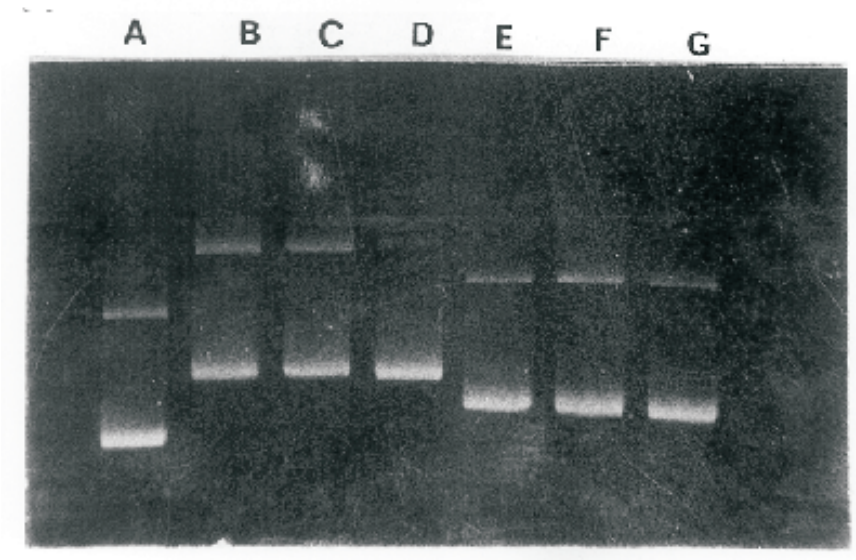

Figure 1. A representative agarose gel separation of recombinant plasmids constructed in the study.

Purified recombinant plasmids (200 ng each) are visualized on ethidium bromide-stained $0.8 \%$ agarose gel. Lane A, pGEM $^{\circledR}$-T plasmid with no insert; lane B, pGEM with H-ori; lane C, pGEM ${ }^{\circledR}$ with L-ori; lane D, pGEM with 800 bp non-mtDNA insert; lane E, pGEM with Term; lane F, pGEM with 400 bp non-mtDNA insert and lane G, pGEM with Cyt- $b$.

A representative agarose gel separation of the recombinant plasmids constructed in the optimization experiments is shown in Fig. 1. Recombinant plasmids are characterized by slower migration than the pGEM-T plasmid with no insert (Fig. 1, lane A), due to the presence of mtDNA sequences (Fig. 1, lanes B, C, $\mathrm{E}$ and $\mathrm{G})$. The experiments also included control plasmids with non-mitochondrial DNA (Fig. 1, lanes D and F, for $800 \mathrm{bp}$ and $400 \mathrm{bp}$ insert groups, respectively), to avoid any effect on ligation of size- and/or sequence-related alterations.

In conclusion, individual reaction parameters were investigated to obtain such set of conditions which gave the highest efficiency in ligation and transformation of plasmids to bacterial cells. Although this study does not rule out the variations that can arise due to in vitro reaction conditions, such as the dNTP pool imbalance, misaligned primer-termini, synthesis time and/or reaction buffer components [9], the results show that T4 PNK-treatment of PCR products without further manipulations with either Klenow or T4 DNA polymerase enzymes, gave the highest number of recombinant clones after $12 \mathrm{~h}$ ligation at $4^{\circ} \mathrm{C}$ using $20 \mathrm{u} / \mathrm{ml} \mathrm{T} 4$ ligase and $10 \mu \mathrm{g} / \mathrm{ml} \mathrm{DNA}$, at an insert to vector ratio of $3: 1$. The data obtained have not been compared to the transformation efficiency obtained by using the supercoiled pUC19 plasmid because the degree of superhelical density, presence of inserts, enzymatic manipulations and mode of transformation can influence the ligation and transformation efficiencies.

The author acknowledges the valuable guidance by Dr. Frank J. Castora throughout the study.

\section{R E F E R E N C E S}

1. Maunders, M.J (1993) DNA polymerases; in Enzymes of Molecular Biology (Burrell, M.M., ed.) pp.7-30, Humana Press, Totawa, New Jersey.

2. Clark, J.M. (1988) Novel non-template nucleotide addition reactions catalyzed by prokaryotic and eukaryotic DNA polymerases. Nucleic Acids Res. 16, 9677-9686.

3. Ausubel, F.M., Bent, R., Kingston, R.E., Moore, D.D. Seidman, J.G., Smith, J.A. \& Struhl, K. (1987) Current Protocols in Molecular Biology, pp. 3.5.1-3.14.4, John Wiley and Sons, New York.

4. Clayton, D.A. (1982) Replication of animal mitochondrial DNA. Cell 28, 693-705.

5. Anderson, S., DeBruijin, M.H.L., Coulson, A.R., Eperon, D.J., Sanger, F. \& Young, I.G. (1982) Complete sequence of bovine mitochondrial DNA. Conserved features of the mammalian mitochondrial genome. J. Mol. Biol. 156, 683-717. 
6. Innis, M.A., Gelford, D.H., Sninsky, J.J. \& White, T.J. (1990) PCR Protocols: A Guide to Methods and Applications, Academic Press, New York.

7. Protocols and Application Guide (1991) Promega Corporation 217, 41.

8. Ullrich, A., Shine, J., Chirgwin, J., Pictet, R., Tischer, E., Rutter, W.J. \& Goodman, H.W.
(1977) Rat insulin genes: Construction of plasmids containing the coding sequences. Science 196, 1313-1319,

9. Eckert, K.A. \& Kunkel, T.A. (1991) DNA polymerase fidelity and the polymerase chain reaction. PCR Methods Appl. 1, 17-24. 